\title{
New Periodicals of $1952-$ Part I
}

Miss Brown is head, Serials Section, Descriptive Cataloging Division, Library of Congress.

$\mathrm{T}$ HE DAILY examination of current periodicals new to the collections of the Library of Congress has been continued during the first six months of 1952. After the elimination of those titles launched prior to this date and quantities of others considered to be of doubtful reference value for one reason or another, only a small number remained for inclusion here.

\section{Book Collecting and Book Reviewing}

The Book Collector Incorporating Book Handbook is published in London. It is planned that this small journal will contain articles of bibliographical information and entertainment together with such regular features as descriptions and illustrations of famous bindings, literary holographs and bibliographical notes and queries. Another "preview" periodical, Religious Book Previews, has been launched. These previews are the authors' descriptive summaries of their own new works and appear in advance of the publication of the books. Scholarly, professional and popular religious books will be reviewed without showing any preference to religious denomination. Each preview will contain a brief statement of the purpose of the book and its background together with descriptions of some of the specific facts, ideas and conclusions with which the book deals.

\section{Literature}

Two new literary journals were started. The Meter Reader, a little magazine of poetry, is presented by the Writers' Club of Springfield, Ohio. The New Generation aims to publish the prose, poetry and art work of persons between the ages of eighteen and twenty-eight.

\section{Music}

The first number of Nordisk Musikkultur, a musical journal for the Scandinavian countries includes articles on composers, compositions and productions and an annotated listing of new recordings.

\section{Genealogy}

Familie und Volk; Zeitschrift für Genealogie und Bevölkerungskunde begins with articles on specific families, specific areas, the evaluation of source materials for genealogical research, annotated lists of new books and lists of new periodical publications.

\section{Medicine}

Laboratory Investigation, a Journal of Technical Method and Pathology has been started to report on new experimental techniques, original investigations and observations on the basic medical sciences. Specifically, papers dealing with pathology, histochemistry, cytologic and histologic methods, tissue culture, comparative pathology, etc. will be published. Metabolism, Clinical and Experimental will publish results secured in laboratories and clinics specializing in the field of metabolism. It is intended to keep the physician who is not an investigator in the field informed as well as to exchange ideas and information among research workers. Articles are accompanied by summaries and bibliographies. Book re- 
views and abstracts from periodicals are to be regular features. The American Journal of Tropical Medicine and Hygiene supersedes American Journal of Tropical Medicine and the Journal of the National Malaria Society. Volume one, number one, is a memorial to Charles Franklin Craig, a doctor whose life was devoted to research in malaria and tropical medicine. Articles are accompanied by summaries and bibliographies. Maryland State Medical Journal is the official publication of the Medical and Chirurgical Faculty of the State of Maryland. The first issue includes notes on the activities of the society along with scientific papers.

\section{Research}

The Boston University Graduate Journal is intended to inform the various departments and schools within the university of the research and scholarly activities of its faculty and students. There will be editorials on current and long-range problems in graduate education and research, articles on unusual and especially interesting projects of graduate students in many fields and descriptions of significant research and instructional or service programs. Although the first issue was but sixteen pages in length it would seem to be a publication which should interest institutions and individuals conducting research.

\section{Mathematics}

A most erudite journal is being published by the Graduate Institute for Applied Mathematics at Indiana University. To quote from its statement of purpose, "the Journal of Rational Mechanics and Analysis nourishes mathematics with physical applications, aiming especially to close the rift between 'pure' and 'applied' mathematics and to foster the discipline of mechanics as a deductive, mathematical science in the classical tradition. Its scope com- prises those parts of pure mathematics or other theoretical sciences which contribute to mechanics; among the included fields are all branches of analysis, differential geometry, analytical dynamics, elasticity, fluid dynamics, plasticity, thermodynamics, relativity, and statistical mechanics."

\section{Economics}

The American Society of Appraisers formed by the union of the American Society of Technical Appraisers and the Technical Valuation Society is issuing Technicalities and Technical Valuation. Such specialities of the appraisal profession as appraising for mortgage purposes, tax assessing, tax reduction, business financing public utility rate-making, depreciation studies and others will be treated. Metal Age published in London reports statistically on the production, shipment, consumption, prices, etc. of ores and metals. Although statistics for the United Kingdom predominate, information from other areas is included.

\section{Political Affairs}

The Forum published monthly in Johannesburg supersedes a weekly publication of the same title. It is a liberal news journal which stands for the expansion of human freedom and opportunity in South Africa. News From Behind the Iron Curtain supersedes an earlier publication of the same title and similar content issued in mimeographed form by the National Committee for a Free Europe. It is a compilation of material collected by the committee for the use of Radio Free Europe and its other divisions and is being made available to representatives of the press, to universities, churches, libraries and research centers and to other groups of citizens who want to know more about "communism in practice." The information is taken from official gazettes, 
newspapers, periodicals and broadcasts from Iron Curtain countries, quoted directly wherever possible and classified as Political, Economic, Cultural and News Briefs. U.S.A., the Magazine of American Affairs is published by the National Association of Manufacturers "as a contribution to public information and understanding of American affairs. The views expressed herein are the authors' and not necessarily those of the National Association of Manufacturers." Among the contributors to the first issue were Senator Byrd, Dr. Herold Hunt, Superintendent of Public Schools, Chicago, and newsman Richard S. Weil.

\section{Law}

Another merger, that of the Journal of Comparative Legislation and The International Law Quarterly resulted in the formation of The International and Comparative Law Quarterly. In this journal there will be discussions of current questions in the fields of comparative law, international law and the conflict of laws. The first issue included articles on "Expropriation and Nationalisation in Hungary, Bulgaria and Roumania," and "Legislation in the Federal Republic of Germany."

\section{Adult Education}

To assist persons who plan and prepare programs and conduct meetings of civic and cultural organizations the Adult Education Association of the U.S.A. has begun the

\section{Periodicals}

Adult Leadership. Adult Education Association of the U.S.A., I20I I6th St., N.W., Washington. v.I, no.I, May 1952. Monthly. \$4.

The American Journal of Tropical Medicine and Hygiene. Williams and Wilkins Co., Baltimore 2. v.I, no.I, January 1952. Bimonthly. $\$ 8$. publication of the monthly Adult Leadership.

\section{Speech Education}

The Speech Teacher as the official publication of the Speech Association of America deals with the problems of teaching speech on all levels, elementary school, high school and university.

\section{Art and Design}

For the professional builder who designs, finances, builds or supplies materials for houses there is being issued The Magazine of Building; House and Home Edition. To improve the quality of design in the home furnishings industry in America, there is Better Design. Both journals are attractively illustrated and would offer many suggestions for the construction and furnishing of new homes.

\section{Orchids}

Another magazine for the orchid grower has appeared, The Orchid Journal from Pasadena, California. Its advisory board made up of persons from Central America, South America, United States, Australia, Singapore and England would indicate that the journal aims to be an international review. It is planned to be helpful to novice and experienced grower alike.

\section{Philately}

The Philatelic Folio somewhat similar in style is intended to interest the general collector as well as the advanced specialist.

Better Design. Good Design Magazine Inc., East Stroudesburg, Pa. v.I, no.I, January 1952. Monthly. \$5.

The Book Collector. The Queen Anne Press, Ltd., 9 Great James St., London, W.C.I. v.I, no.I, Spring 1952. Quarterly. II s. Boston University Graduate Journal. Boston University Graduate School, 725 Common- 
wealth Ave., Boston 15. v.I, no.I, April 1952. Monthly (except July-August). Free?

Familie und Volk. Degener und Co., Berchtesgaden. v.I, no.I, January/February 1952. Bimonthly. $\mathrm{DM}_{7} 8$ o.

The Forum. I76 Main St., Johannesburg. v.1, no.I, April 1952. Monthly. 13 s.

The International and Comparative Law Quarterly. Society of Comparative Legislation, 18 Northumberland Ave., London, W.C.2. v.1, no.I, January 1952. 30 s.

Journal of Rational Mechanics and Analysis. Graduate Institute for. Applied Mathematics, Indiana University, Bloomington. v.I, no.I, January 1952. I v. a year. \$18.

Laboratory Investigation. P.B. Hoeber, Inc., 49 East 33d St., New York i6. v.I, no.I, Spring 1952. Quarterly. \$8.

The Magazine of Building. House and Home Edition. Time Inc., 9 Rockefeller Plaza, New York 20. v.I, no.I, January 1952. Monthly. \$5.50.

Maryland State Medical Journal. I2II Cathedral St., Baltimore I. v.I, no.I, January 1952. Monthly. \$5.

Metabolism, Clinical and Experimental. Grune and Stratton, Inc., 38r Fourth Ave., New York I6. v.I, no.I, January 1952. Bimonthly. \$9.

Metal Age. Metal Information Bureau, Ltd., 27 Albermarle St., London, W.r. no.I, January 1952. Monthly. 25 s.

The Meter Reader. Writers' Club, Spring- field, Ohio. 1952. Frequency not given. Price not given.

The New Generation. 603 South Main St., Geneva, N.Y. Summer 1952. Quarterly. $50 \phi \dot{~ p e r}$ copy.

News From Behind the Iron Curtain. Research and Publications Service, National Committee for a Free Europe, Inc., I Io W. 57th St., New York 19. v.I, no.I, January 1952. Monthly. Free.

Nordisk Musikkultur. Sigurd Berg, Hammerensgade 3, Köbenhavn. no.I, 1952. Frequency not given. Price not given.

The Orchid Journal. 132 W. Union St., Pasadena, Calif. v.I, no.I, January 1952. Monthly. \$5.

The Philatelic Folio. L.F. Livingston, 2435 North Charles St., Baltimore I8. v.I, no.I, March 1952. Quarterly. \$2.

Religious Book Previews. 3I Markham Road, Princeton, N.J. v.I, no.I, January 1952. Quarterly. \$4.25.

The Speech Teacher. Speech Association of America, 12 E. Bloomington St., Iowa City, Iowa. v.I, no.I, January 1952. 4 no. a year. $\$ 3.50$.

Technicalities and Technical Valuation. E.D. Crawford, P.O. Box 107, Jamaica, N.Y. v.I, no.I, February 1952. Quarterly. Price not given.

U.S.A., the Magazine of American Affairs. National Association of Manufacturers, 350 E. $22 \mathrm{~d}$ St., Chicago I6. v.I, no.I, March 1952. Monthly. \$3.

\section{Librarian, What of the Book Jacket?}

\section{(Continued from page 322)}

extremely helpful if the designer's name and the year of publication appear on them. On the Continent, the name of the designer often appears in the book, but not on the jacket. Since such collections redound to the glory, even perhaps to the profit of the publisher, his cooperation may not unfairly be asked.

The attitude toward book jackets of private book collectors, who have played such an important role in building up the resources of libraries, has been fully dis-

\footnotetext{
" Kohn, John S. Van E., "Some Notes on Dust Jackets," Publishers' Weekly, 132:1732-35, October 30, 1937.
}

cussed by Mr. Kohn. ${ }^{7}$ To what extent jackets as such are privately collected is difficult to say. They are not bought and sold in the market place as are other collector's items, but usually can be obtained only with and at the price of the book itself, a formidable deterrent to collecting them separately. Only one private book jacket collection, to the present writer's knowledge, has been described in print, that of W. A. D. Englefield's Rex Whistler collection. ${ }^{8}$ There are probably many others.

8 "Check List of Rex Whistler Book-Wrappers." Book-Collectors' Quarterly (London) April-June 1935, p. 64-9. 